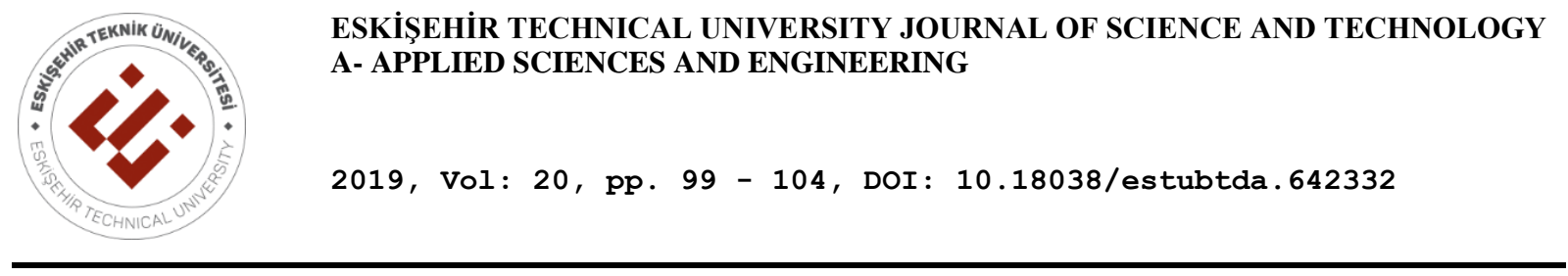

\title{
STRUCTURAL ANALYSIS AND ORBITAL INTERACTIONS OF PROLINE
}

\author{
Saliha ILICAN*, Nihal KUŞ \\ Department of Physics, Science Faculty, Eskisehir Technical University, Yunus Emre Campus, 26470 Eskisehir, Turkey
}

\begin{abstract}
In this work, proline (Pro) was studied theoretically at the Density Functional Theory (DFT) methods with B3LYP/6$311++G(d, p)$ level and four conformers with minimum energy were found. The calculations were done for these conformers. Electronic energies, Gibbs energies, the Highest Occupied Molecular Orbital (HOMO) and Lowest Unoccupied Molecular Orbital (LUMO) energy values were calculated. The Natural Bond Orbital (NBO) interactions were analyzed, and plotted. Electron density surfaces of the selected NBOs for Pro conformers showing the dominant orbital interactions, calculated at the Becke3LYP/6-311++G(d,p) level, were drawn. For Pro conformers, orbital energies for NBO pairs were calculated by Fock matrix equation.
\end{abstract}

Keywords: Amino Acid, Proline, NBO

\section{INTRODUCTION}

Amino acids are organic molecules of great biological importance. Although there are more than seven hundred amino acids in nature, only 20-22 of them are basic amino acids encoded by DNA and forming proteins. The difference in the number, variety and sequence of amino acids results in the different types of proteins in each living being [1-3]. Therefore, it is very important to know their structures. Among these proline (Pro; IUPAC: Pyrrolidine-2-carboxylic acid; $\mathrm{C}_{5} \mathrm{H}_{9} \mathrm{NO}_{2}$ ) is a proteinogenic (protein creating) amino acid that is used in the biosynthesis of proteins.

In present study, the approximate geometry of the Pro in three dimensions was drawn in the GaussView 5.0 molecular imaging program [4] to get stable state and the space arrangement of the atoms in the molecule. Natural Bond Orbital (NBO) calculations of the Pro were made and analyzed.

\section{THEORITICAL DETAILS}

The calculation of energies and optimization for the Pro conformers were performed using the Density Functional Theory (DFT) integrated in the Gaussian 09 [5] program. The calculations were done using the 6-311++G(d,p) basis set. The three-parameter hybrid density functional, which includes Becke's gradient exchange correction [6] and the Lee, Yang and Parr [7], is called Becke3LYP. Stabilization energies and orbital analysis of the Pro were clarified using the NBO theory. The method was used considering Weinhold and co-workers, by NBO 3.1 [8] as integrated in Gaussian 09.

\section{RESULTS AND DISCUSSION}

Pro molecule was optimized using DFT with Becke3LYP/6-311++G(d,p) basis set and the geometries of this molecule with minimum energy. This molecule has four conformers (Figure 1). According to the calculations, Pro1 is more stable than the other three conformers. The calculated energies of all the Pro conformers are tabulated in Table 1.

*Corresponding Author: silican@eskisehir.edu.tr

Received: 10.10.2019 Published: 16.12.2019 


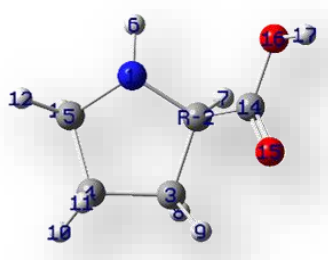

Pro1

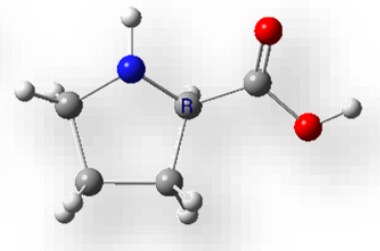

Pro2

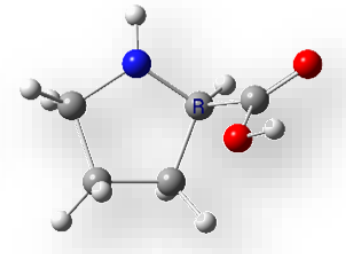

Pro3

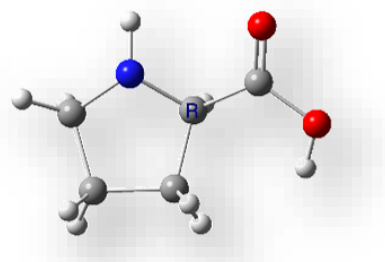

Pro4

Figure 1. The molecular structure of Pro and its conformers, calculated by Becke3LYP/6-311++G(d,p) level

Table 1. Calculated electronic energies (with and without zero point vibrational energy), Gibbs energies, and their relative energies, dipole moments, obtained from Becke3LYP/6-311++G(d,p) calculations.

\begin{tabular}{ccccc}
\hline Energies & Pro1 & Pro2 & Pro3 & Pro4 \\
\hline E(R3BLYP) (hartree) & -401.27910 & -401.27825 & -401.27780 & -401.26963 \\
E(ZPV) (hartree) & -401.13511 & -401.13439 & -401.13376 & -401.12603 \\
Gibbs (hartree) & -401.16864 & -401.16762 & -401.16708 & -401.15911 \\
$\boldsymbol{\mu}$ (debye) & 2.2928 & 2.2465 & 2.4518 & 5.0133 \\
$\Delta \mathbf{E}\left(\mathbf{k J ~ m o l}^{-1}\right)$ & 0 & 2.228 & 3.423 & 24.874 \\
$\Delta$ E $(\mathbf{Z P V})\left(\mathbf{k J ~ m o l}^{-\mathbf{1}}\right)$ & 0 & 1.882 & 3.537 & 23.847 \\
$\Delta \mathbf{G}\left(\mathbf{k J ~ m o l}^{-1}\right)$ & 0 & 2.681 & 4.098 & 25.016 \\
\hline
\end{tabular}

Conformers of the Pro molecule were found depending on the arrangements of the carboxylic group. In this arrangements, three low energy conformations (Pro1, Pro2 and Pro3) were formed when the dihedral angle of the carboxylic group $\mathrm{N}-\mathrm{C}-\mathrm{C}=\mathrm{O}$ was 0 degrees. The formation of the high-energy conformer (Pro4) was determined by the scanning of $\mathrm{O}=\mathrm{C}-\mathrm{O}-\mathrm{H}$ dihedral angle. Calculated ground state potential energy surface of the Pro were plotted in Figures 2 and 3.

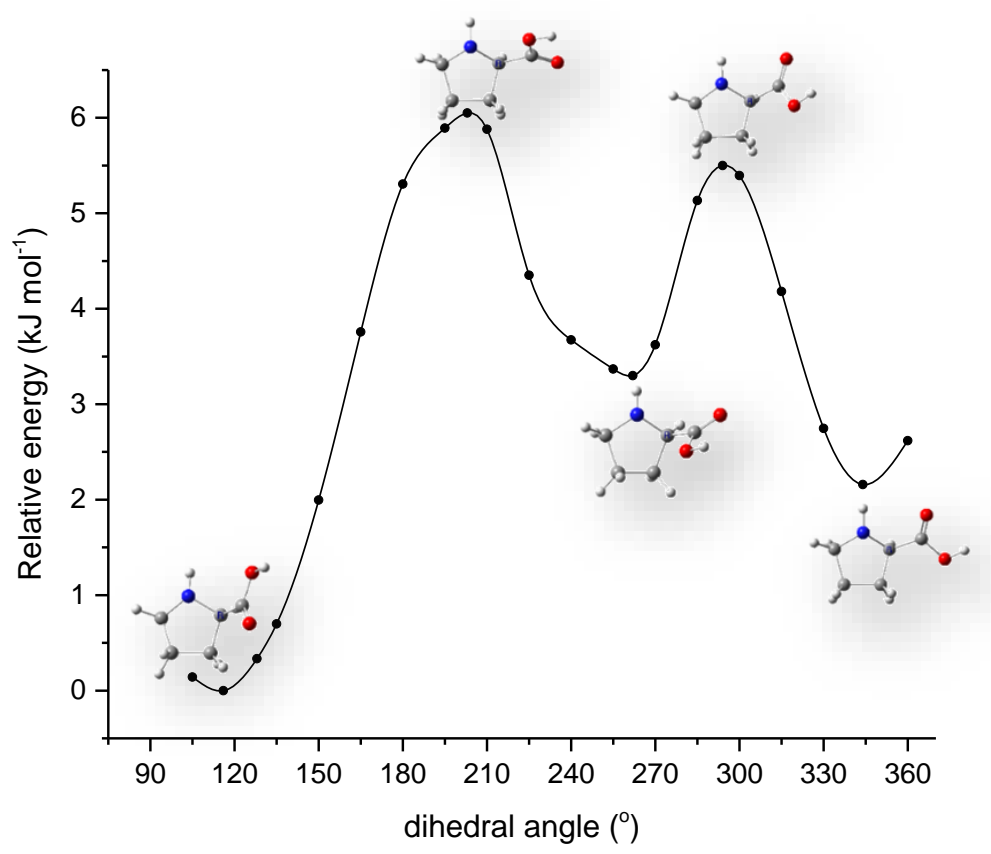

Figure 2. Potential energy profile resulting from the rotation of the $\mathrm{N}-\mathrm{C}-\mathrm{C}=\mathrm{O}$ dihedral angle in 15 degree steps.

According to the calculations, the Pro1 conformer is more stable than the Pro3 conformer by $c a .3 .42$ $\mathrm{kJ} \mathrm{mol}^{-1}$, the Pro $1 \rightarrow$ Pro3 barrier amounts to $c a .5 .89 \mathrm{~kJ} \mathrm{~mol}^{-1}$, and a the Pro $2 \rightarrow$ Pro3 barrier amounts 
to $c a .3 .34 \mathrm{~kJ} \mathrm{~mol}^{-1}$. The Pro2 conformer is more stable than the Pro3 form by $c a .1 .20 \mathrm{~kJ} \mathrm{~mol}^{-1}$, and the Pro2 $\rightarrow$ Pro3 barrier amounts to $c a .2 .97 \mathrm{~kJ} \mathrm{~mol}^{-1}$.

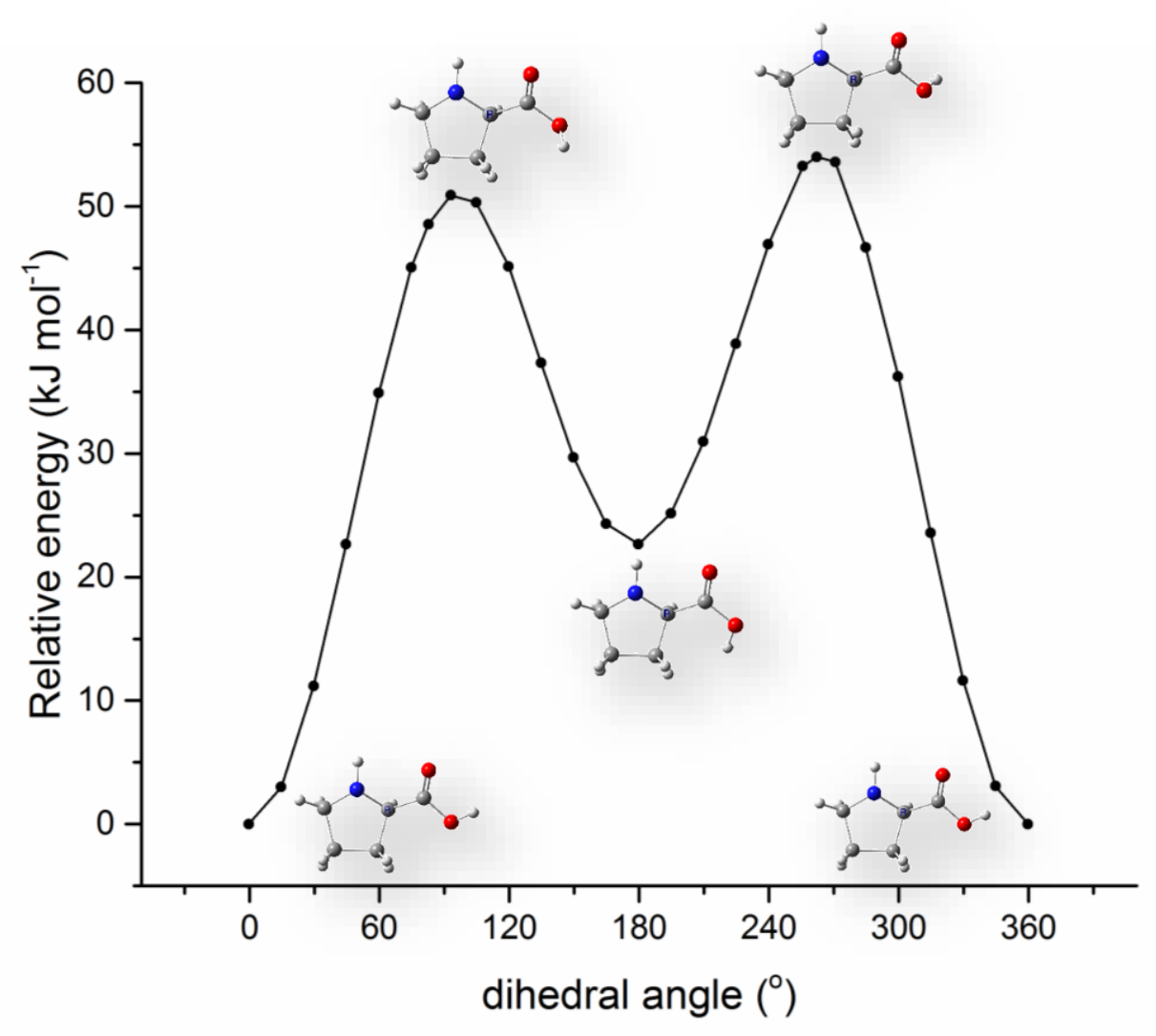

Figure 3. Potential energy profile resulting from the rotation of the $\mathrm{O}=\mathrm{C}-\mathrm{O}-\mathrm{H}$ dihedral angle in 15 degree steps.

The Pro 2 conformer is more stable than the Pro 4 conformer by $c a .22 .70 \mathrm{~kJ} \mathrm{~mol}^{-1}$, and the Pro $\rightarrow$ Pro4 barrier amounts to $c a .50 .30 \mathrm{~kJ} \mathrm{~mol}^{-1}$, and reversible barrier amounts to $c a .53 .24 \mathrm{~kJ} \mathrm{~mol}^{-1}$.

The energies given in the Table 2 were calculated using the Fock matrix equation. $E(2)$ stabilization energies, between filled (donor; lone pairs ) and empty (acceptor; non Lewis and Rydberg orbitals) NBOs, were estimated by the second-order perturbation approach [9],

$$
E(2)=\Delta E_{i j}=q_{i} \frac{F_{i j}^{2}}{\varepsilon_{j}-\varepsilon_{i}}
$$

where $q_{i}$ is the donor orbital occupancy, $\varepsilon_{i}$ and $\varepsilon_{j}$ are the diagonal elements and $F_{i j}$ is NBO the offdiagonal NBO Fock matrix element.

According to the NBO results, the strongest polarization exhibited from oxygen atom $(\mathrm{O} 16)$ to $\mathrm{C} 14-\mathrm{O} 15$ bond. And they were hybridized pure $p$ character. the second strong polarization was from oxygen atom (O15) to $\mathrm{C} 14-\mathrm{O} 16$ bond and hybridized as a $s p^{2}$ character. NBO interactions for all conformers are given in Table 2. 


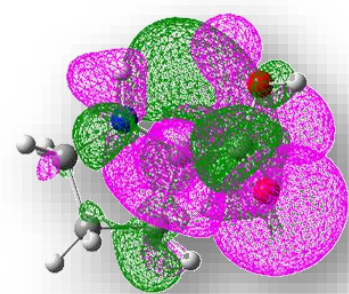

A1

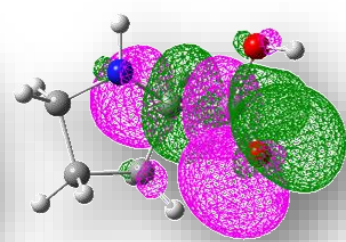

B1

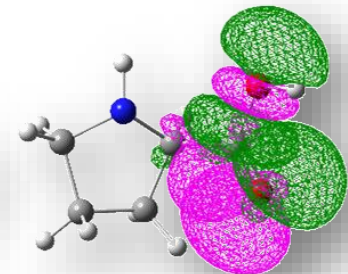

$\mathrm{C} 1$

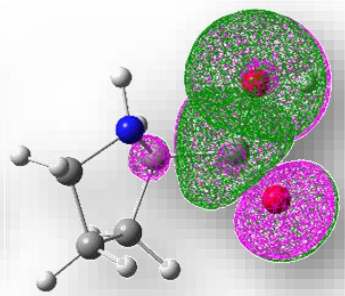

D1

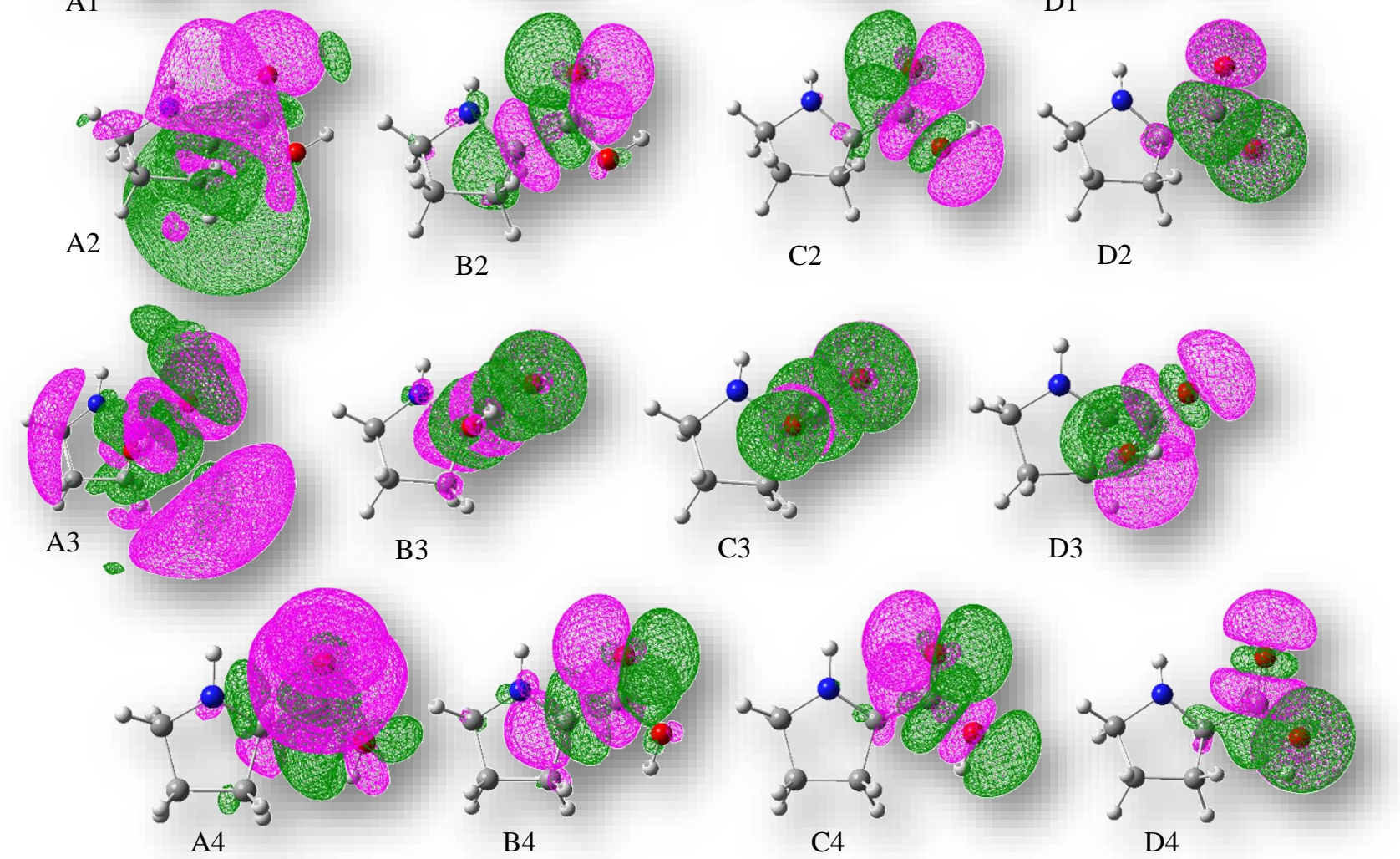

A4

C4
D4

Figure 4. Electron density surfaces for the selected NBOs of all Pro conformers calculated at the Becke3LYP/6 311++G(d,p) level effective orbital interactions (given in Table 2). green and pink and indicate the states of positive and negative wave functions, respectively.

As seen in Table 2, the most important NBO interactions of Pro1 and Pro2 conformers are of the same type, at the same time their relative significance is similar with each other's. For Pro1 and Pro2, interactions of types $C$ and D show delocalization as a $\pi$-system of the molecule (Figure 4, D1 and D2) and reflected over the $\mathrm{C}=\mathrm{O}$ bond between lone pair orbital of $\mathrm{O} 16 . \mathrm{C} 1$ and $\mathrm{C} 2$ pairs interacted as a $\sigma$ type (Figure 4, C1 and C2). This conclusion agreed with the study of acrylic acid [10]. On the other hand, for Pro3 and Pro4, the most orbital interaction types are $\sigma$-type (Figure 4, C3, D3, C4 and D4).

For all conformers, NBO analyzes associated with orbital pairs A and B were not considered, as there were less significant orbital interactions. 
Table 2. Donor and acceptor pairs, orbital energies for NBO pairs as calculated by the Fock matrix equation (Eq.1) in the NBO basis for Pro $^{\text {a }}$.

\begin{tabular}{|c|c|c|c|c|c|c|}
\hline Conformer & Pair & $\begin{array}{c}\text { Donor NBO } \\
(i) \\
\end{array}$ & $\begin{array}{c}\text { Acceptor NBO } \\
(j)\end{array}$ & $\begin{array}{c}E(2) \\
\mathrm{kJ} \mathrm{mol}^{-1} \\
\end{array}$ & $\begin{array}{c}\varepsilon_{j-} \varepsilon \\
\text { au }\end{array}$ & $\begin{array}{l}F_{i j} \\
\text { au }\end{array}$ \\
\hline \multirow{4}{*}{ Pro1 } & A1 & LP1(O15) & Ry1*(C14) & 73.69 & 1.67 & 0.153 \\
\hline & B1 & LP2(O15) & $\sigma^{*}(\mathrm{C} 2-\mathrm{C} 14)$ & 75.53 & 0.64 & 0.098 \\
\hline & $\mathrm{C} 1$ & LP2(O15) & $\sigma^{*}(\mathrm{C} 14-\mathrm{O} 16)$ & 140.70 & 0.61 & 0.130 \\
\hline & D1 & LP2(O16) & $\pi^{*}(\mathrm{C} 14=\mathrm{O} 15)$ & 179.36 & 0.35 & 0.111 \\
\hline \multirow{4}{*}{ Pro2 } & $\mathrm{A} 2$ & LP1(O15) & Ry1*(C14) & 71.85 & 1.71 & 0.153 \\
\hline & $\mathrm{B} 2$ & LP2(O15) & $\sigma^{*}(\mathrm{C} 2-\mathrm{C} 14)$ & 78.46 & 0.65 & 0.098 \\
\hline & $\mathrm{C} 2$ & LP2(O15) & $\sigma^{*}(\mathrm{C} 14-\mathrm{O} 16)$ & 141.49 & 0.61 & 0.130 \\
\hline & D2 & LP2(O16) & $\pi^{*}(\mathrm{C} 14=\mathrm{O} 15)$ & 178.28 & 0.35 & 0.110 \\
\hline \multirow{4}{*}{ Pro3 } & A3 & LP1(O15) & Ry1*(C14) & 68.26 & 1.71 & 0.149 \\
\hline & B3 & LP2(O15) & $\sigma^{*}(\mathrm{C} 2-\mathrm{C} 14)$ & 71.44 & 0.64 & 0.095 \\
\hline & $\mathrm{C} 3$ & LP2(O15) & $\sigma^{*}(\mathrm{C} 14-\mathrm{O} 16)$ & 140.36 & 0.61 & 0.130 \\
\hline & D3 & LP2(O16) & $\sigma^{*}(\mathrm{C} 14=015)$ & 181.62 & 0.35 & 0.111 \\
\hline \multirow{4}{*}{ Pro4 } & A4 & LP1(O15) & Ry1*(C14) & 75.07 & 1.70 & 0.156 \\
\hline & B4 & LP2(O15) & $\sigma^{*}(\mathrm{C} 2-\mathrm{C} 14)$ & 77.96 & 0.63 & 0.099 \\
\hline & $\mathrm{C} 4$ & LP2(O15) & $\sigma^{*}(\mathrm{C} 14-\mathrm{O} 16)$ & 141.83 & 0.60 & 0.129 \\
\hline & D4 & LP2(O16) & $\sigma^{*}(\mathrm{C} 14=\mathrm{O} 15)$ & 166.99 & 0.36 & 0.108 \\
\hline
\end{tabular}

${ }^{a}$ See atom numbering in Figure 1. LP: lone pair orbital, Ry: Rydberg orbital.

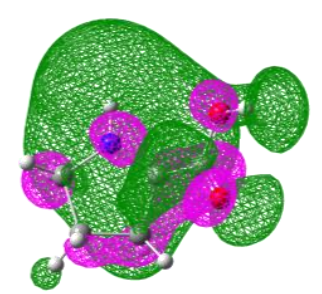

$5.92 \mathrm{eV}$

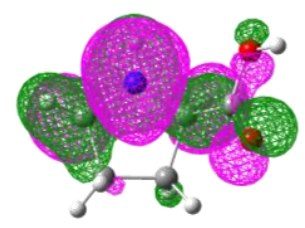

Pro1

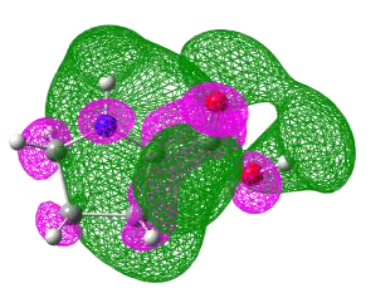

$5.93 e V$

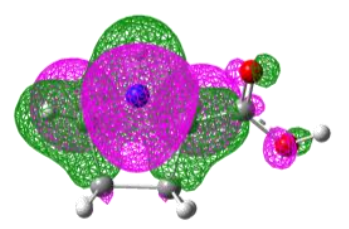

Pro2

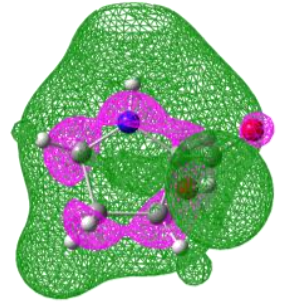

$5.94 e V$

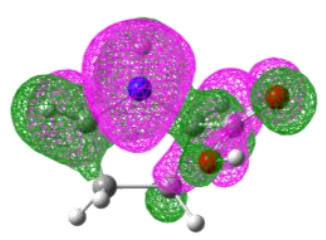

Pro3

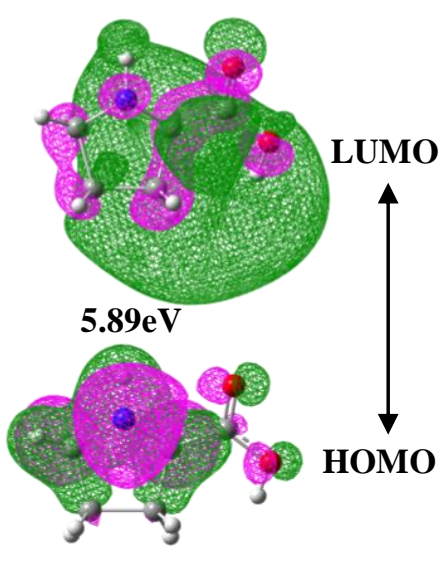

Pro4

Figure 5. The difference of HOMO-LUMO energies for all the conformers of Pro calculated at the Becke3LYP/6 311++G(d,p) level.

Energy gaps between the Highest Occupied Molecular Orbital (HOMO) and Lowest Unoccupied Molecular Orbital (LUMO) for Pro conformers (the calculated with the DFT/6-311++G(d,p)) and their orbital schemes are shown in Figure 5. These values are 5.92, 5.93, 5.94 and $5.89 \mathrm{eV}$ in gas phase for Pro1, Pro2, Pro3 and Pro4, respectively. 


\section{CONCLUSIONS}

The conformers of Pro were calculated in the ground electronic state using B3LYP/6-311++G(d,p) level. Pro1 was more stable than the other conformers ca. $2.23,3.42$ and $24.87 \mathrm{~kJ} \mathrm{~mol}^{-1}$, respectively. The stabilization energies of the Pro molecule were determined using the NBO method. It was used potential energy profiles to plotted the barrier energies. Most important orbital interactions of conformers were analyzed and discussed. HOMO-LUMO energies were also determined and their orbitals were plotted.

\section{ACKNOWLEDGEMENT}

This work was supported by Eskisehir Technical University Commission of Research Project under Grant no. 19ADP143.

\section{REFERENCES}

[1] Wagner I, Musso H. New Naturally Occurring Amino Acids. Angew Chem Int Ed Engl 1983; 22 (11): 816-828.

[2] Michalski MC, Januel C. Does homogenization affect the human health properties of cow's milk?. Trends Food Sci Technol 2006; 17: 423-437.

[3] E-Dalatony MM, Saha S, Govindwar SP, A-Shanab RAI, Jeon BH. Biological Conversion of Amino Acids to Higher Alcohols. Trends Biotechnol. 2019; 37: 855-869.

[4] Dennington R, Keith T, Millam J. Gauss View, Version 5. Semichem Inc, Shawnee Mission, 2009.

[5] Frisch MJ, Trucks GW, Schlegel HB, Scuseria GE, Robb MA, Cheeseman JR, Scalmani G, Barone V, Mennucci B, Petersson GA, Nakatsuji H, Caricato M, Li X, Hratchian HP, Izmaylov AF, Bloino J, Zheng G, Sonnenberg JL, Hada M, Ehara M, Toyota K, Fukuda R, Hasegawa J, Ishida M, Nakajima T, Honda Y, Kitao O, Nakai H, Vreven T, Montgomery JA, Peralta Jr JE, Ogliaro F, Bearpark M, Heyd JJ, Brothers E, Kudin KN, Staroverov VN, Kobayashi R, Normand J, Raghavachari K, Rendell A, Burant JC, Iyengar SS, Tomasi J, Cossi M, Rega N, Millam JM, Klene M, Knox JE, Cross JB, Bakken V, Adamo C, Jaramillo J, Gomperts R, Stratmann RE, Yazyev O, Austin AJ, Cammi R, Pomelli C, Ochterski JW, Martin RL, Morokuma K, Zakrzewski VG, Voth GA, Salvador P, Dannenberg JJ, Dapprich S, Daniels AD, Farkas O, Foresman JB, Ortiz JV, Cioslowski J, Fox DJ. Gaussian 09, Revision A.0.2. Gaussian Inc, Wallingford CT, 2009.

[6] Becke AD. "Density-functional exchange-energy approximation with correct asymptotic behavior". Phys Rev A 1988; 38, 3098-3100.

[7] Lee C, Yang W, Parr RG. Development of the Colle-Salvetti correlation-energy formula into a functional of the electron density. Phys Rev B 1988; 37: 785-789.

[8] Reed AE, Curtiss LA, Weinhold F. Intermolecular interactions from a natural bond orbital, donoracceptor viewpoint. Chem Rev 1988; 88: 899-926.

[9] Weinhold F, Landis CR. Valency and Bonding. A Natural Bond Orbital Donor-Acceptor Perspective. Cambridge University Press: New York, 2005.

[10] Kuş N, Ai Y-J, Fang W-H, Fausto R. Photorotamerization of matrix-isolated acrylic acid revisited. J Chem Phys 2011; 134: 154306. 